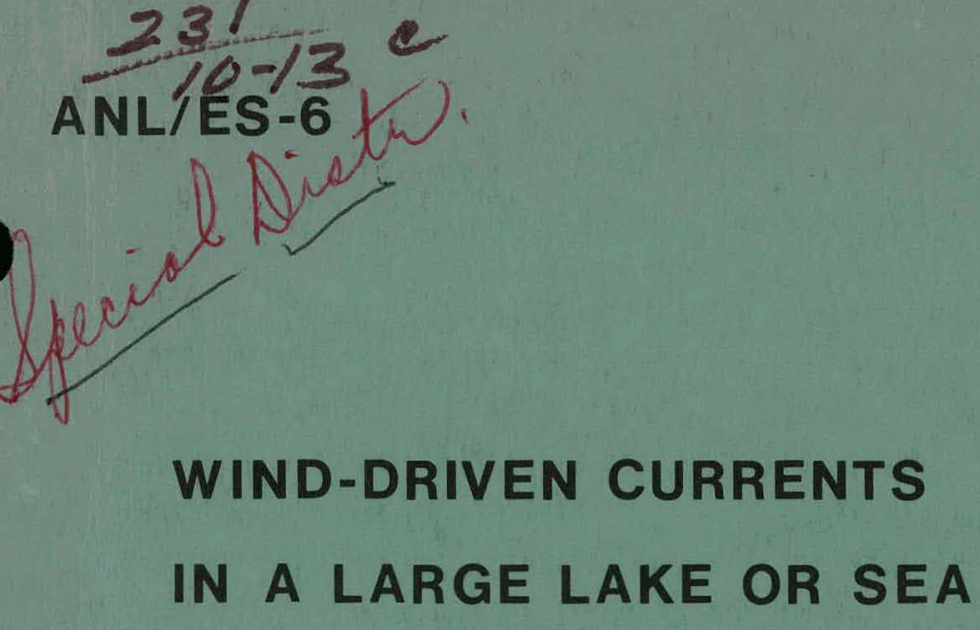

\section{WIND-DRIVEN CURRENTS \\ IN A LARGE LAKE OR SEA}

G. E. Birchfield

\section{Uc-2 \\ UC-}

ANL/ES-6

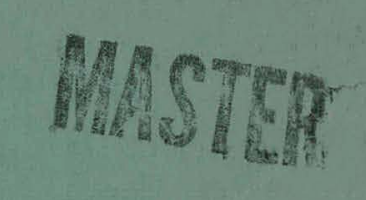

THIS DOCUMENT CONFIRMED AS

INCLAS SIFIEO

DIVISION OF CLASUIFICATION

BY q Hahn ghelamb 


\section{DISCLAIMER}

This report was prepared as an account of work sponsored by an agency of the United States Government. Neither the United States Government nor any agency Thereof, nor any of their employees, makes any warranty, express or implied, or assumes any legal liability or responsibility for the accuracy, completeness, or usefulness of any information, apparatus, product, or process disclosed, or represents that its use would not infringe privately owned rights. Reference herein to any specific commercial product, process, or service by trade name, trademark, manufacturer, or otherwise does not necessarily constitute or imply its endorsement, recommendation, or favoring by the United States Government or any agency thereof. The views and opinions of authors expressed herein do not necessarily state or reflect those of the United States Government or any agency thereof. 


\section{DISCLAIMER}

Portions of this document may be illegible in electronic image products. Images are produced from the best available original document. 
The facilities of Argonne National Laboratory are owned by the United States Government. Under the terms of a contract (W-31-109-Eng-38) between the U. S. Atomic Energy Commission, Argonne Universities Association and The University of Chicago, the University employs the staff and operates the Laboratory in accordance with policies and programs formulated, approved and reviewed by the Association.

\section{MEMBERS OF ARGONNE UNIVERSITIES ASSOCIATION}

The University of Arizona. Carnegie-Mellon University Case Western Reserve University The University of Chicago University of Cincinnati Illinois Institute of Technology Univer sity of Illinois Indiana University Iowa State University The University of Iowa
Kansas State University The University of Kansas Loyola University Marquette University Michigan State University The University of Michigan University of Minnesota University of Missouri Northwestern University University of Notre Dame
The Ohio State University Ohio University The Pennsylvania State University Purdue University Saint Louis University Southern Illinois University The University of Texas at Austin Washington University Wayne State University The University of Wisconsin

\section{NOTICE}

This report was prepared as an account of work sponsored by the United States Government. Neither the United States nor the United States Atomic Energy Commission, nor any of their employees, nor any of their contractors, subcontractors, or their employees, makes any warranty, express or implied, or assumes any legal liability or responsibility for the accuracy, completeness or usefulness of any information, apparatus, product or process disclosed, or represents that its use would not infringe privately-owned rights.

Printed in the United States of America Available from

National Technical Information Service

U.S. Department of Commerce 5285 Port Royal Road

Springfield, Virginia 22151

Price: Printed Copy $\$ 3.00$; Microfiche $\$ 0.95$ 


\section{ARGONNE NATIONAL LABORATORY \\ 9700 South Cass Avenue \\ Argonne, Illinois 60439}

\section{WIND-DRIVEN CURRENTS IN A LARGE LAKE OR SEA \\ by}

G. E. Birchfield*

Applied Mathematics Division

Work performed in part under the auspices of the

U.S. Atomic Energy Commission

and

National Science Foundation, Atmospheric Sciences Section,

Grant No. GA-1078

July 1971

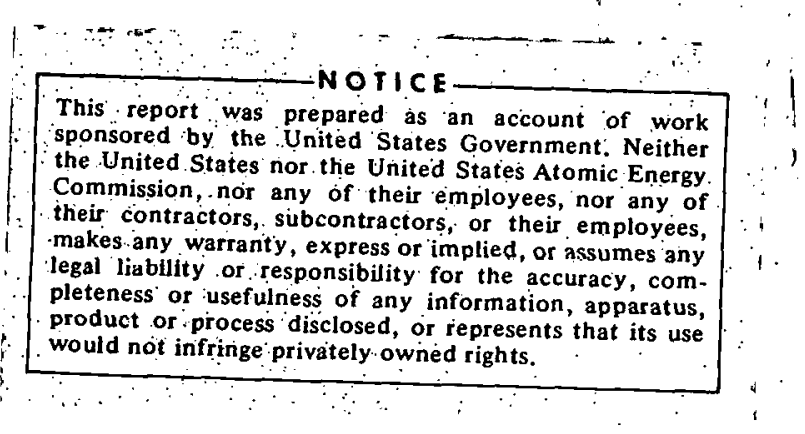

* Departments of Engineering Scicnces and Geological Sciences, Northwestern University, Evanston, Illinois 
THIS PAGE

\section{WAS INTENTIONALLY LEFT BLANK}


TABLE OF CONTENTS

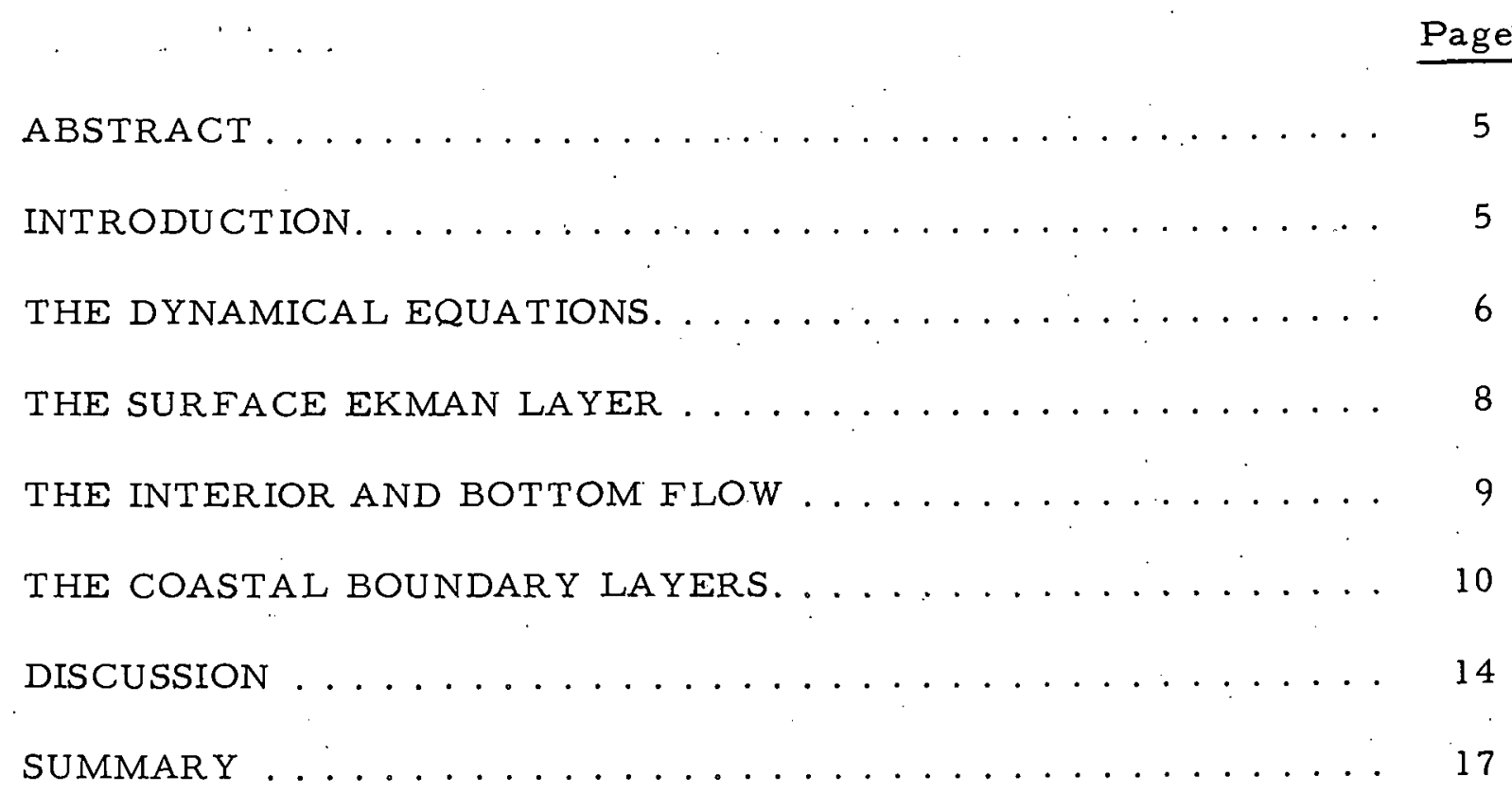


THIS PAGE

WAS INTENTIONALLY

LEFT BLANK 
WIND-DRIVEN CURRENTS IN A LARGE LAKE OR SEA

\author{
by \\ G. E. Birchfield
}

\begin{abstract}
A linear model of the Ekman dynamics for a large shallow homogeneous lake or sea is constructed to examine the mass transport balance, in particular the vertical mass flux. The role of coastal upwelling is examined for steady uniform and nonuniform wind-stress forcing.
\end{abstract}

\title{
INTRODUCTION
}

The purpose of this report is to construct a greatly simplified model of the wind-driven currents in a large lake or sea in order to examine how the Ekman dynamics bring about horizontal and vertical mass balance. The model incorporates the earth's rotation, and the Rossby number is assumed small enough to neglect the convective terms in the equations of motion. Horizontal and vertical turbulent mixing is incorporated in the simplest way. Because the horizontal scale of wind systems is large relative to the lake size, the model wind stress is taken as either uniform or with uniform curl, and steady in time. The important feature of small mean-depth-towidth ratio of a large lake is imposed on the model. The geometry of the model has, however, been simplified to a rectangular basin of uniform depth.

Questions to be considered concern: (1) how horizontal mass transport is partitioned between the Ekman layer transports and the geostrophic transport; (2) how the surface drift transport normal to a coast is returned to the interior of the basin; (3) how mass flux balance is achieved for a divergent surface Ekman layer; and (4) whether coastal jets appear with a uniform depth and constant Coriolis parameter. These questions and the method used to pursue them are similar to those of Pedlosky* (henceforth referred to as $P$ ), who considered an ocean basin. The principaldifference here is that the variation of the Coriolis parameter with latitude may be neglected. This significantly alters the dynamics and resulting circulation.

The model used here obviously lacks many important features of a real lake or sea. Because of the simplification of the turbulent effects, the

*J. Pedlosky, An Overlooked Aspect of the Wind-Driven Oceanic Circulation, J. Fluid Mech. $32,809-821$ (1968). 
details of the coastal circulations must be regarded with caution. Sufficient elements of the geophysical situation are incorporated, however, to provide some insight into the necessary viscous constraints on the mass transport away from the coastal regions.

\section{THE DYNAMICAL EQUATIONS}

The model lake or sea is a rectangular basin of width $L$, length $M L$, and uniform depth $D$; the lake is homogeneous with density $p$. It will be assumed that the horizontal dimensions of the lake are large enough for the earth's rotation to be important, but small enough so that the variation of the vertical component of the angular velocity may be nrglertier. The explicit condition for the latter assumption is discussed below. The equations of motion for steady state are

$$
\left.\begin{array}{rl}
u u_{x}+v u_{y}+w u_{z}-f v & =-\frac{p_{x}}{\rho}+A_{H}\left(u_{x x}+u_{y y}\right)+A_{v} u_{z z}, \\
u v_{x}+v v_{y}+w v_{z}+f u & =-\frac{p_{y}}{\rho}+A_{H}\left(v_{x x}+v_{y y}\right)+A_{v} v_{z z}, \\
u w_{x}+v w_{y}+w w_{z} & =-\frac{p_{z}}{p_{\rho}}+A_{H}\left(w_{x x}+w_{y y}\right)+A_{v} w_{z z},
\end{array}\right\}
$$

and

$$
u_{x}+v_{y}+w_{z}=0
$$

where

$$
f=2 \Omega_{0}\left(1+\frac{\beta_{0}}{2 \Omega_{0}} y\right)
$$

is the Coriolis parameter, $\Omega_{0}$ and $\beta_{0}$ are constants, and the $y$-axis is directed north; $z$ increases upward from the basin bottom; and $u, v$, and $w$ are the velocity components. Eddy viscosity coefficients for the horizontal. $A_{H}$. and vertical, $A_{v}$, are assumed constant. Currents are generated by a.surface wind stress

$$
\vec{T}=\tau(x, y) \hat{j},
$$

where $\hat{j}$ is a unit vector along the $y$-axis.

Dimensionless variables are introduced with primes: 


$$
\begin{aligned}
& (\mathrm{u}, \mathrm{v})=\dot{U}\left(\mathrm{u}^{\prime}, \mathrm{v}^{\prime}\right), \quad \mathrm{w}=\frac{\mathrm{D}}{\mathrm{L}} \mathrm{U} \mathrm{w}^{\prime \prime} \\
& (x, y)=L\left(x^{\prime}, y^{\prime}\right), z=D z^{\prime}, \\
& p=\rho U L \Omega_{0} p^{\prime \prime}, \quad T=\tau_{0} \tau^{\prime}, \quad \Omega^{\prime \prime}=1+A^{\prime \prime \prime} y^{\prime \prime}, f^{\prime \prime} \equiv 2 \Omega^{\prime \prime}, \\
& U \equiv \sqrt{1 / \Omega_{0} A_{V}} \tau_{0} / \rho, \quad \beta^{\prime} \equiv \beta_{0} L / 2 \Omega_{0}
\end{aligned}
$$

and

and

$$
u_{x}+v_{y}+w_{z}=0
$$

where $\nabla_{2}^{2}=\partial^{2} / \partial x^{2}+\partial^{2} / \partial y^{2}$ and $\vec{v}=u \hat{i}+v \hat{j}+w \hat{k}$. The boundary conditions are

$$
\begin{aligned}
& \text { at } x=0,1 ; y=0, M ; z=0: u=v=w=0 ; \\
& \text { at } z=1: u_{z}=0 ; v_{z}=E_{v}^{-1 / 2} \tau(x, y) ; w=0
\end{aligned}
$$

Five nondimensional numbers appear:

$\varepsilon=\mathrm{U} / \Omega_{0} \mathrm{~L}$, the Rossby number,

$E_{H}=A_{H} / \Omega_{0} L^{2}$, the horizontal Ekman number,

$\mathrm{E}_{\mathrm{v}}=\mathrm{A}_{\mathrm{v}} / \Omega_{0} \mathrm{D}^{2}$, the vertical Ekman number,

$\delta=D / L$, the aspect ratio,

and

$\beta=\beta_{0} L / 2 \Omega_{0}$, nondimensional $d f / d y$.

Only surall amplitude motions will be considered; that is, terms multiplied by $\epsilon$ will be neglected.: As done in $P, E_{V}$ and $E_{H}$ will be 
replaced by $E$ in view of the lack of reliable information as to their magnitudes. The qualitative character of the flow should not be altered. It is further assumed that $L$ is sufficiently small that

$$
B<E^{1 / 2}<<1
$$

may be assumed; that is, to a first approximation, $f$ may be replaced by 2 , except possibly where differentiated.

\section{THE SURFACE EKMAN LAYER}

Away from the side walls of the basin. we assume the flow variables to be represented by the sum of three parts; letting $\vec{v}=u \hat{i}+v \hat{j}$, we obtain

$$
\begin{aligned}
& \vec{v}=\vec{v}_{1}(x, y, z)+\vec{v}_{2}(x, y, \zeta)+\vec{v}_{3}\left(x, y, \zeta^{\prime}\right), \\
& w=w_{1}(x, y, z)+w_{2}(x, y, \zeta)+w_{3}\left(x, y, \zeta^{\prime}\right),
\end{aligned}
$$

and

$$
p=p_{1}(x, y, z)+p_{2}(x, y, \zeta)+p_{3}\left(x, y, \zeta^{\prime}\right)
$$

These represent the interior or inviscid part (subscript 1), the surface Ekman corrections (subscript 2), and the bottom Ekman corrections (subscript 3$)$. The stretched variable in the surface layer is $\zeta \equiv E^{-1 / 2}(z-1)$ and at the bottom $\zeta^{\prime}=E^{-1 / 2} z$. Each component solution represents an asymptotic series in $E$, in particular:

$$
\begin{aligned}
& \vec{v}_{1}(x, y, z)=\vec{v}_{11}+E^{1 / 4} \vec{v}_{12}+E^{1 / 2} \vec{v}_{13}+\ldots ; w_{1}(x, y, z)=E^{1 / 2} w_{13}+\ldots ; \\
& p_{1}(x, y, z)=p_{11}+E^{1 / 4} p_{12}+E^{1 / 2} p_{13}+\ldots ; \\
& \vec{v}_{2}(x, y, \zeta)=\vec{v}_{21}+0(E) ; w_{2}(x, y, \zeta)=E^{1 / 2} w_{23}+\ldots ; p_{2}=0(E) ; \\
& \vec{v}_{3}\left(x, y, \zeta^{\prime}\right)=\vec{v}_{31}+E^{1 / 4} \vec{v}_{32}+E^{1 / 2} \vec{v}_{33}+\ldots ; w_{3}=E^{1 / 2} w_{33}+\ldots ; \\
& p_{3}=0(E) .
\end{aligned}
$$

The upper Ekman correction solutions are of the standard form and are simply stated:

$$
\begin{aligned}
& u_{21}(x, y, \zeta)=\frac{1}{2} \tau(x, y) e^{\zeta}(\cos \zeta-\sin \zeta) ; \\
& v_{21}(x, y, \zeta)=\frac{1}{2} \tau(x, y) e^{\zeta}(\cos \zeta+\sin \zeta) ; \\
& w_{23}(x, y, 0)=-\frac{1}{2} \hat{k} \cdot \operatorname{cur} 1 \dot{\tau}=-\frac{1}{2} \frac{\partial T}{\partial x} .
\end{aligned}
$$


If we assume $\beta=b E^{n}$, where $b$ and $n$ are constants greater than or equal to zero, the vorticity equation for the uniform depth model is found to be, from Eq. 4 ,

$$
-2\left(1+b E^{n_{y}}\right) \frac{\partial w}{\partial z}+2 b E^{n_{v}}=E \nabla^{2} w ; w=v_{x}-u_{y}
$$

To accept the vertical mass flux from the surface layer, $E^{1 / 2} w_{23}(x, y, 0)$, an interior vertical velocity $0\left(E^{1 / 2}\right)$ is required. For a large lake or sea, $n$ is greater than $1 / 2$, and hence, for the interior flow, $\partial w / \partial z$ is zero. A horizontally nondivergent bottom Ekman layer with $0\left(E^{1 / 2}\right)$ vertical velocities is required. This then requires $0(1)$ interior geostrophic velocities.

For the assumed solution (Eq. 6), it is found that at least up to $O\left(E^{1 / 2}\right)$. the interior variables satisfy equations of the form

and

$$
\left.\begin{array}{rl}
-2 v_{11} & =-p_{11 x}, \\
+2 u_{11} & =-p_{11 y}, \\
0 & =-p_{11 z},
\end{array}\right\}
$$

and

$$
u_{11 x}+v_{11 y}=0 ; \quad w_{13 z}=0
$$

The interior flow is hydrostatic, geostrophic, and nondivergent. The vertical velocity is determined from matching with the surface layer:

$$
w_{13}(x, y)=:-w_{23}(x, y, 0)=\frac{1}{2} \hat{k} \cdot \operatorname{curl} \vec{T}
$$

The bottom boundary layer is a conventional Ekman layer: From Eq. 6, it is found that

and

$$
\begin{aligned}
& u_{31}\left(x, y, \zeta^{\prime}\right)=-\left(u_{11} \cos \zeta^{\prime}+v_{11} \sin \zeta^{\prime}\right) e^{-\zeta^{\prime}}, \\
& v_{31}\left(x, y, \zeta^{\prime}\right)=-\left(v_{11} \cos \zeta^{\prime}-u_{11} \sin \zeta^{\prime}\right) e^{-\zeta^{\prime}}
\end{aligned}
$$

$$
\mathrm{w}_{33}(\mathrm{x}, \mathrm{y}, 0)=-\frac{i}{2} \hat{\mathrm{k}} \cdot \operatorname{curl} \overrightarrow{\mathrm{v}}_{11}
$$


If the interior velocity is represented by a: stream function,

$$
u_{11}=-\frac{\partial \psi_{11}}{\partial y}, \quad v_{11}=\frac{\partial \psi_{11}}{\partial x}
$$

then using the bottom boundary condition to match the interior vertical velocity, we have

$$
\nabla^{2} \Psi_{11}=\hat{k} \cdot \operatorname{curl} \vec{\tau}=\frac{\partial \tau}{\partial x}
$$

This is a statement that the generation of vorticity by the wind stress is balanced by the dissipation at the bottom. Since $\|_{11}=0$ on the copot, to bring the normal velocity to zero, the interior flow is determined to this order.

\section{THE COASTAL BOUNDARY LAYERS}

The interior horizontal mass transport. is $\left(U_{1}, V_{1}\right)=\left(u_{11}, v_{11}\right)+0\left(E^{1 / 4}\right)$. To the lowest order, the transport normal to the lateral boundaries vanishes, as in the usual small $\beta$ transport theory. To discuss the mechanics of the $0\left(E^{1 / 2}\right)$ Ekman transport, the surface drift transport and the vertical Ekman suction transport, however, we must extend the solution up to and including $0\left(E^{1 / 2}\right)$. This requires analysis of coastal viscous layers, which for this model means the waili boundary layers.

The surface drift transport from Eq. 7. is

$$
\left.\begin{array}{l}
\mathrm{U}_{2}(\mathrm{x}, \mathrm{y})=\mathrm{E}^{1 / 2} \int_{-\infty}^{0} \mathrm{u}_{21} \mathrm{~d} \zeta=\frac{1}{2} \mathrm{E}^{1 / 2} \tau(\mathrm{x}, \mathrm{y})+\ldots ; \\
\mathrm{V}_{2}(\mathrm{x}, \mathrm{y})=\mathrm{E}^{1 / 2} \int_{-\infty}^{0} \mathrm{v}_{21} \mathrm{~d} \zeta=0+\ldots
\end{array}\right\}
$$

The mass flux associated with viscous flow at the bottom, from Eq. 10, is:

$$
\left.\begin{array}{l}
U_{3}(x, y)=-\frac{1}{2} E^{1 / 2}\left(u_{11}+v_{11}\right)+\ldots ; \\
v_{3}(x, y)=\frac{1}{2} E^{1 / 2}\left(v_{11}-u_{11}\right)+\ldots .
\end{array}\right\}
$$

The total horizontal mass transport is then.

$$
\mathrm{U}=\sum_{\mathrm{i}=1}^{3} \mathrm{U}_{\mathrm{i}}, \mathrm{V}=\sum_{\mathrm{i}=1}^{3} \mathrm{~V}_{\mathrm{i}}
$$


Since $\beta .<1$, there will be no $\mathrm{E}^{1 / 3}$. boundary layer on the western coast. In fact, with the absence of $\beta$, the structure will be essentially the same on all four coasts. There exists an outer layer of thickness $E^{1 / 4} \mathrm{~L}$, which is hydrostatic and geostrophic. It brings the interior longshore velocity to zero. It accepts the bottom Ekman flux $0\left(E^{1 / 2}\right)$ and transports it up the wall. A thinner viscous region of thickness $E^{1 / 2} \mathrm{~L}$, identical to that occurring in $P$, is needed to connect the interior flow with the surface Ekman layer.

As in $\mathrm{P}$, a much thinner layer of thickness $\delta \mathrm{L}$ is required to bring the vertical velocity to zero at the wall; this layer plays no role in the mass balance to lowest order.

The only difference between the viscous layers occurring at $\dot{x}=0,1$ and those at $y=0, M$ will arise from there being no normal surface-drift transport at the latter two coasts, since the surface stress is directed in the $y$ direction. It is therefore sufficient to discuss in detail the viscous layers occurring only at $x=0$. By a simple transformation, solutions at the remaining coasts may be obtained.

In the vicinity of $x=0$, let $x=E^{1 / 4} \eta$; the dependent variables are

$$
\left.\begin{array}{l}
u=u_{1}+E^{1 / 4} \hat{u}(\eta, y)+\ldots \\
v=v_{1}+\hat{v}(\eta, y)+\ldots \\
w=w_{1}+E^{1 / 4} \hat{w}(\eta, y, z)+\ldots, \\
p=p_{1}+E^{1 / 4} \hat{p}(\eta, y)+\ldots
\end{array}\right\}
$$

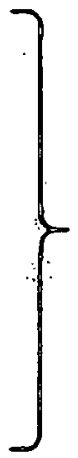

and

The correction variables denoted by a $\wedge$ satisfy the equations

$$
\begin{aligned}
& 0=-\hat{\mathrm{p}}_{\eta}+2 \hat{\mathrm{v}}, \\
& 0=-\hat{\mathrm{p}}_{\mathrm{y}}-2 \hat{\mathrm{u}}+\mathrm{E}^{1 / 4} \hat{\mathrm{v}}_{\eta \eta}, \\
& 0=-\hat{\mathrm{p}}_{\mathrm{z}},
\end{aligned}
$$

and

$$
0=\hat{u}_{\eta}+\hat{v}_{y}+E^{1 / 4} \hat{w}_{z}
$$

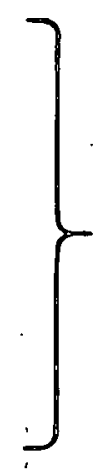

The correction flow has a horizontal divergence $0\left(E^{1 / 4}\right)$. The second momentum equation may be written

$$
\hat{\mathrm{u}} \equiv \hat{\mathrm{u}}_{\mathrm{a}}+\mathrm{E}^{1 / 4} \hat{\mathrm{u}}_{\mathrm{b}} \cong-\frac{1}{2} \hat{\mathrm{p}}_{\mathrm{y}}+\frac{1}{2} E^{1 / 4} \hat{v}_{\eta \eta} .
$$


That is, the normal correction velocity in the $E^{1 / 4}$ region has two parts: a geostrophic part $0\left(E^{1 / 4}\right)$ and a divergent part $0\left(E^{1 / 2}\right)$. Only the latter plays a role in the mass balance.

The vorticity equation is

$$
0=-2 \frac{\partial \hat{w}}{\partial z}-\hat{v}_{\eta \eta \eta}
$$

Since $\hat{v}$ is independent of $z, \hat{w}$ is a linear function of $\dot{z}$. For the bottom boundary condition to be satisfied, an Ekman layer is required in the independent variables $x=E^{1 / 4} \uparrow, z=E^{1 / 2} \zeta^{\prime}$; again this is a standard divergent Ekman layer near $z=0$. If $\hat{w}(\eta, y, z)=(1-z) \hat{w}(\eta, y, 0)$, the Ekman suction at $\mathbf{z}=0$ requires

$$
\hat{w}(\eta, y, z)=\frac{1}{2} \hat{v}_{\eta}(1-z)
$$

The vorticity equation reduces to

$$
\hat{\mathrm{v}}_{\eta \eta \eta}-\hat{\mathrm{v}}_{\eta}=0
$$

at $\mathbf{x}=0$ we must have $\cdot \dot{v}_{11}+\hat{v}=0$. Hence,

$$
\begin{aligned}
& \hat{v}(\eta, y)=-v_{11}(0, y) e^{-\eta}, \\
& \hat{w}(\eta, y, z)=\frac{1}{2}(1-z) v_{11}(0 ; y) e^{-\eta},
\end{aligned}
$$

and

$$
\hat{u}(\eta, y)=\frac{-\partial v_{11}}{\partial y}(0, y) e^{-\eta}-\frac{1}{2} E^{1 / 4} v_{11}(0, y) e^{-\eta}
$$

The vertical mass flux is

$$
\hat{W}=E^{1 / 2} \cdot \int_{0}^{\infty} \hat{w} \cdot d \eta=\frac{1}{2} E^{1 / 2}(1-z) v_{11}(0, y)
$$

This layer, having nonvanishing normal velocities at the coast, in turn forces higher-order interior velocities. To fully discuss the mass balance, we must consider these terms. The $0\left(E^{1 / 4}\right)$ interior flow satisfies equations of the form of Eq. 9. Since there is no additional interior vertical velocity required, the matching bottom Ekman layer is nondivergent, and hence the second-order interior flow satisfies

$$
\nabla_{2}^{2} \psi_{12}=0
$$


where $\psi_{12}$ is the stream function for the $0\left(E^{1 / 4}\right)$ flow. Boundary conditions force the flow, e.g.,

$$
x=0: u_{12}(0, y)=\frac{-\partial \psi_{12}}{\partial y}=-\hat{u}(0, y)=\frac{\partial v_{11}}{\partial y}(0, y)
$$

The third-order interior flow $0\left(E^{1 / 2}\right)$, is forced not only by the $E^{1 / 4}$ layer, but the thinner $\mathrm{E}^{1 / 2}$ layer discussed next.

Since the $E^{1 / 2}$ layer is so similar to that in $P$ (see $P$, Sec. 5 and appendix), only an abbreviated derivation will be given. If we let $x=E^{1 / 2} \xi$, the expansion for the flow variables ( $\mathrm{Eq}$. 14) will have the following added terms:

$$
\left.\begin{array}{rl}
u & =\ldots+E^{1 / 2} \tilde{u}(\xi, y)+\ldots \\
v & =\ldots+E^{1 / 2} \tilde{v}(\xi, y)+\ldots \\
w & =\ldots+\tilde{w}(\xi ; y, z)+\ldots \\
p & =\ldots+0\left(E^{5 / 4}\right)+\ldots
\end{array}\right\}
$$

and

The tilda variables satisfy

$$
\begin{aligned}
& 0=2 \tilde{\mathrm{v}}+\tilde{\mathrm{u}}_{\xi \xi}, \\
& 0=-2 \tilde{\mathrm{u}}+\tilde{v}_{\xi \xi},
\end{aligned}
$$

and

$$
0=\tilde{\mathrm{u}}_{\xi}+\tilde{\mathrm{w}}_{z}
$$

The flow is hydrostatic, but not geostrophic. If $\tilde{\mathrm{u}}=\partial \tilde{\psi} / \partial z, \tilde{w}=-\partial \tilde{\psi} / \partial \xi$, these reduce to

$$
\frac{\partial^{2}}{\partial z^{2}}(\widetilde{\psi} \xi \xi \xi \xi+4 \tilde{\psi})=0
$$

The solution is found to be

$$
\begin{aligned}
& \mathrm{E}^{1 / 2} \widetilde{\psi}(\xi, \mathrm{y}, \mathrm{z})=\mathrm{ze}-\xi\left[\mathrm{U}_{2}(0, \mathrm{y}) \cos \xi+\mathrm{V}_{2}(0, \mathrm{y}) \sin \xi\right]=z \mathrm{U}_{2}(0, y) \mathrm{e}^{-\xi} \cos \xi \\
& \mathrm{E}^{1 / 2} \tilde{\mathrm{u}}(\xi, \mathrm{y})=\mathrm{U}_{2}(0, \mathrm{y}) \mathrm{e}^{-\xi} \cos \xi
\end{aligned}
$$


$E^{1 / 2} \tilde{v}(\xi, y)=U_{2}(0, y) e^{-\xi} \sin \xi$

and

$\mathrm{E}^{1 / 2} \tilde{\mathrm{w}}(\xi, \mathrm{y}, \mathrm{z})=\mathrm{z} \mathrm{U}_{2}(0, \mathrm{y}) \mathrm{e}^{-\xi}(\cos \xi+\sin \xi)$,

where use has been made of the fact that $V_{2} \equiv 0$. The vertical mass flux is

$$
\tilde{W}(y, z)=E^{1 / 2} \int_{0}^{\infty} \tilde{w}(\xi, y, z) d \xi=E^{1 / 2} \tilde{\psi}(0, y, z)=z U_{2}(0, y) .
$$

The forcing for the third-order interior flow $0\left(E^{1 / 2}\right)$ now becomes apparent. Since the $0\left(\mathrm{E}^{1 / 2}\right)$ interior flow is also geostrophic and nondivergent, we have again

$$
\nabla_{2}^{2} \Psi_{13}=0
$$

where $\psi_{13}$ is the stream function for $\left(u_{13}, v_{13}\right)$. The boundary forcing comes from imposing that the total normal $0\left(E^{1 / 2}\right)$ velocity vanishat the coast; that is,

$$
\mathbf{x}=0: \hat{\mathrm{u}}_{\mathrm{b}}(0, \mathrm{y})+\tilde{\mathrm{u}}(0, \mathrm{y})+\mathrm{u}_{13}(0, \mathrm{y})=0,
$$

or

$$
\left.-\frac{1}{2} v_{11}(0, y)+E^{-1 / 2} U_{2}(0, y)-\frac{\partial \psi_{13}}{\partial y}=0 .\right\}
$$

\section{DISCUSSION}

The case of vanishing curl $\vec{T}$ is simplest to discuss. If $\tau=\tau(y)$, curl $\vec{i} \equiv 0$. The Ekman suction vanishes from the surface layer; with no vertical flux of mass in the interior, no $0(1)$ bottom Ekman laye $r$ is required, hence no interior velocity $0(1)$. Further, with no $0(1)$ interior velocities, no coastal layers of thickness $0\left(E^{1 / 4}\right)$ are required. There remain: the uniform (in $\mathrm{x}$ ) horizontal Ekman transport,

$$
\mathrm{U}_{2}(\mathrm{y})=\frac{1}{2} \mathrm{E}^{1 / 2} \mathrm{~T}(\mathrm{y}) ;
$$

the $O\left(E^{1 / 2}\right)$ geostrophic interior flow,

$$
E^{1 / 2} u_{13}(y)=-U_{2}(y)
$$

and

$$
E^{1 / 2} v_{13}=0,
$$


and the viscous $E^{1 / 2}$ upwelling coastal layer at $\mathbf{x}=0,1$. The surface current is essentially that of the Ekman layer, that is, $45^{\circ}$ to the right of the wind stress. Lines of constant free surface height are perpendicular to the wind stress and with maximum setup downwind. The surface drift transport is returned via the interior at each value of $y$, with downwelling at $x=1$, upwelling at $\mathrm{x}=0(\tau>0)$.

In discussing the case of nonvanishing $\hat{k} \cdot \operatorname{curl} \vec{\tau}$, let

$$
T(x)=\bar{T}+\Delta\left(x-\frac{1}{2}\right)
$$

where $\bar{T}>0, \Delta<0$ are constants. Then the interior $0(1)$ flow is found from Eq. 11:

$$
\nabla^{2} \psi_{11}=\Delta
$$

where

$$
\psi_{11}=0 \text { on all coasts; }
$$

the interior flow is a single symmetric clockwise gyre. There is a uniform downward exit of mass from the surface Ekman layer to the bottom Ekman layer. The total flux is

$$
W_{I}=E^{1 / 2} \int_{S} w_{11} d S=\frac{1}{2} E^{1 / 2} \cdot \int_{S} \hat{k} \cdot \operatorname{curl} \vec{T} d S=\frac{1}{2} E^{1 / 2} M \Delta<0,
$$

where $S$ is the area of the basin. This mass flux begins its return from the bottom to the surface Ekman layer at the coasts in the $E^{1 / 4}$ viscous layer. From Eq. 20, the total vertical flux in the $E^{1 / 4}$ layer is found by integrating around the four sides of the basin. It is found that

$$
\hat{W}_{T}=-\frac{1}{2} E^{1 / 2}(1-z) \oint_{C} \vec{v}_{11} \cdot d \vec{s}=-\frac{1}{2} E^{1 / 2}(1-z) \Gamma
$$

and

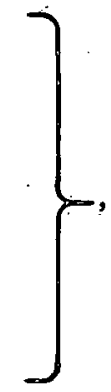

where $C$ is a horizontal contour encircling the basin, and $\Gamma$ is the geostrophic circulation $0 .(1)$ at the coast. By application of Stokes' theorem to Eq. 32 and use of Eq. 11, Eq. 29 yields 


$$
\Gamma=\int_{S} \hat{k} \cdot \operatorname{curl} \vec{\tau} d S=M \Delta
$$

and

$$
\left.\hat{\mathrm{W}}_{\mathrm{T}}=-\frac{1}{2} E^{1 / 2}(1-z) \int_{S} \hat{\mathrm{k}} \cdot \operatorname{curl} \vec{\tau} \cdot \mathrm{d} S=-\frac{1}{2} E^{1 / 2} M \Delta(1-z) \quad\right]
$$

Note that this upwelling occurring on all coasts depends only on curl $\vec{T}$ and not directly on the stress itself. The vertical flux decreases from a maximum at $\mathbf{z}=0$, to zero at $\mathbf{z}-1$,

The total vertical mass flux in the $E^{1 / 2}$ layer is found in a similar way by integrating around the basin; using Eq. 25, we have

$\tilde{W}_{T}=-z \oint_{C} \vec{V}_{2} \cdot \hat{n} \mathrm{ds}=\frac{1}{2} \mathrm{E}^{1 / 2} z \oint_{\mathrm{C}} \hat{\mathrm{k} x \vec{\tau}} \cdot \overrightarrow{\mathrm{ds}}=-\frac{1}{2} \mathrm{E}^{1 / 2} \mathrm{z} \mathrm{M} \Delta>0$

where $\vec{V}_{2}=U_{2} \hat{i}+V_{2} \hat{j}$, and $\hat{n}$ is the outward normal to the coast. Since $\overrightarrow{\mathrm{V}}_{2} \cdot \hat{\mathrm{n}}=0$ on $\mathrm{y}=0, \mathrm{M}$, the $E^{1 / 2}$ vertical flux occurs only on the coasts parallel to the wind stress: upwelling at $x=0$, downwelling at $x=1$; the flux depends directly on the wind stress. Since $U_{2}(0)$, the normal surface drift transport at $x=0$, is larger than $U_{2}(1), \tilde{W}_{T}$ is positive. For uniform stress, $\tilde{W}_{T}=0$; the upwelling exactly balances the downwelling, and the return flow. was via the $0\left(\mathrm{E}^{1 / 2}\right)$ interior flow. With nonvanishing curl $\vec{\tau}$, the $0\left(E^{1 / 2}\right)$ geostrophic interior flow performs the same task; hut. an additional source of mass influx to the interior flow is needed to supply the extra mass at $x=0$. This flux comes from the convergence of the vertical mass flux $\hat{W}_{\mathrm{T}}$ in the $\mathrm{E}^{1 / 4}$ layer; the horizontal outflow into the $\mathrm{E}^{1 / 2}$ interior field is brought about by the divergent part of the $\mathrm{E}^{1 / 4}$ layer normal velucity: Extending Eq. 12 to all sides of the basin and integrating, we find that the flux entering the interior horizontal flow from the $E^{1 / 4}$ layer is

$$
-E^{1 / 2} \oint_{C} \overrightarrow{\hat{v}}_{b} \cdot \hat{n} d s=-\frac{1}{2} E^{1 / 4} \oint_{C^{\prime}} \vec{v}_{11} \cdot d \vec{s}=-\frac{1}{2} E^{1 / 2} \Gamma \text {, }
$$

which is exactly the flux entering the $E^{1 / 4}$ layer at the bottom of the coastal walls. The horizontal. $0\left(E^{1 / 2}\right)$ interior flow streamlines may be constructed. schematically. Streamlines emanate from the three coasts at $x=1, y=0, M$ and converge on the coast at $x=0$, returning horizontally the downwelling flux at $x=1$, and the upwelling flux from the bottom Ekman layer, which in turn originates from the Ekman suction flux from the surface layer. With the $O\left(E^{1 / 2}\right)$ horizontal flow constructed, the mass flux balance is complete. 


\section{SUMMARY}

For the rectangular uniform-depth basin, with no gradient of earth's vorticity present $(\beta=0)$, and for a simple wind stress $\vec{\tau}=\tau(x) \hat{j}$, there is downwelling $\frac{1}{2} E^{1 / 2} \tau(1)$ on the coast to the right of the wind stress and upwelling $\frac{1}{2} E^{1 / 2} \tau(0)$ on the left coast via an $E^{1 / 2}$ wall layer. The downwelling mass is returned horizontally across the basin to the upwelling coast by an $O\left(E^{1 / 2}\right)$ geostrophic interior flow. The vertical flux of mass out of the divergent surface Ekman layer (Ekman suction) is transported to the bottom friction layer and thence horizontally to the coasts. Although this mass begins its return to the surface by ascending the coastal walls (via the $E^{1 / 4}$ vertical layer), it does not continue directly to the free surface, instead being forced again out into the interior. As part of the $0\left(E^{1 / 2}\right)$ horizontal geostrophic return flow, it moves to the upwelling coast and thence to the surface friction layer. Large [0(1)] geostrophic interior flow is required to produce the necessary stress for the bottom friction layer.

The simple wind stress was chosen solely for its effectiveness in permitting visualization of the circulation; a general steady stress can be treated with no more mathematical complexity. The artificiality of the rectangular geometry can also be easily removed to an arbitrary smooth closed coastline, thereby eliminating the special corner regions. The constraint of depth uniformity cannot be removed as easily. Preliminary analysis indicates, however, that much of the circulation mechanics is unchanged for the basin containing closed depth contours; the most significant alteration, arising from the Taylor-Proudman constraint, appears to be that the horizontal $0\left(E^{1 / 2}\right)$ geostrophic return flow is pushed out of the interior and instead occurs in viscous coastal layers of thickness $0\left(E^{1 / 4}\right)$. 
ANL/ES-6

Standard distribution by DTIE

Standard Distribution List WASTE HEAT DISPOSAL

U. S. Atomic Energy Commission (25 copies)

Number

of Copies

U.S. Atomic Energy Commission

Assistant Director for Nuclear Safety

Division of Reactor Development and Technology

bashington, D.C.' 20545

1

U.S. Atomic Energy Commission

Assistant Director for Program Analysis

Division of Reactor Development and Technology

Washington, D.C. 20545

3

U.S. Atomic Energy Comission

Assistant Director for Radiological Pnysics

Division of Biology and Medicine

Washington, D.C. 20545

1

U.S. Atomic Energy Commission

Chief, Environmental Scicnces Branch

Division of Biology and hedicine

Vlashington, D.C.' 20545

3

U.S. Atomic Energy Comission

Director, Division of Compliance, DR

Washington, D.C. $20545^{\circ}$

U.S. Atomic Energy Commission

Director, Division of Radiation

Protection Standards, DR.

Washington, D.C. 20545

5

U.S. Atomic Energy Commission

Director, Division of Reactor Licensing, DR

Vashington, D.C. 20545

5

U.S. Atomic Energy Comnission

Director, Division of Reactor Standards, DR

Washington, D.C. 20545

2

U.S. Atomic Energy Commission

Director, Office of Environmental Affairs

Washington, D.C. 20545

1

U.S. Atonic Energy Commission

Diracton of Regulation

Washington, D.C. 20545

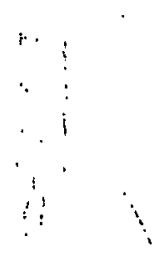

2 
12

National Inaboratorics (18 copies)

Mrganne National Laboratory

Associate Director, Radiological Physics. Division

9700 South Cass Avenue

Argonne, Illinois 60732

2

Argonne National Laboratony

Center for Envixomental Studies

9700 South-Eass Avenue

Angonke, Illinois 60439

Battelle Nemorial Institute

Pacific Northriest Laboratony

P.0. Box 999

Richland, Vashington 99352

Oak Riclge National Laboratory

Associate Director for Biomedical and Environmental Sciences

Oak Ridge, Tennessee 37830

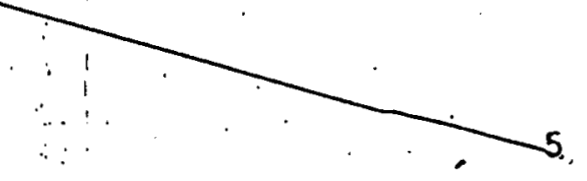

Oak Ridge National Laboratory

Associate Director for Reactor and Engineering Sciences

Oak Ridge, Tennessee 37830

Oak Ridge National Laboratory. Nuclear Safety Information Center P.O. BoX Y

Oak Ridge, Tennessee 37830

Federal Agencies ( 29 copies)

Bonneville Poner Administration

1002 NE Holladay

Portland, Oregon 97208

Environmental Protection A.gency

Chief, National Thermal Pollution Research Staff

Office of Water Quality

Facific Northrest Vater Laboratory

Corvallis, Oregon 97330

Environmental Protection Agency

Division of Hater Quality Research.

Orfice of Water Quality

Washington, D.C. 20242 
Environmental Frotection Agency

Nid. $\Lambda$ thantic Office of Water Quality

918 Enrnet Strcet

Charlottesville, Virginia 22901

1

Environmental Protection Agency

Regional Director, Great Lakes Office of Hatcr Quality

1 North Wacker Drive

Chicago, Illinois 60606

Environmental Protection Agency Parklarm Building 5,500 Fishers Lane

Rockville, Maryland 20852

Federal Power Commission

Advisor on Environmental Quality

44 I G Street, in

Washington, D.C. 20426

National Marine Water Quality Laboratory

P.O. Box 277

West Kingston, Rhode Island 02892

National Oceanographic Data Center

Building 160, Navy Yand Annex

Washington, D.C. 20390

Naval Research Laboratory

Directon of Research for Oceanology

Code 3000

Vashington, D.C. 20390

2

Office, Chief of Army Engineers

U.S. Department of the Army

hashington, D.C. 20315

Office of Science $\&$ Techuviogy

Assistant Director for Energy and Environment

Executive Office of the President

Roorn 207

Executive Office Building

Vashington, D.C. 20506

Office of Science and Technology

Chairman, Interagency Committee on Hater.

Resources Research

- Executive Office Building

Washington, D.C. 20506 
Teuncssee Valley suithority

Assistant to the Dircctor

Division of Environmental Research and Development

'i20 Eaney Building

Chattanooga, Tennessee 37401

U.S. Nepartment of the Interior

Fish and Wildific Service

Bureau of Cominercial Fisheries

Hashington, D.C. 20240

U.S. Department of the Interior

Fish and lildlife Service

Burcau of Sport Fisheries and rildife

Washington, D.C. 20240

U.S. Departinent of the Interior

Office of Saline Water

Washington, D.C. 20240

U.S. Depariment of the Interior

Office of Water Resources Research

Washington, D.C. 20242

1

U.S. Departinent of the Interior

Sandy Hook Narine Laboratory

Highlancis, New Jersey 07732

U.S. Department of the Interior

U.S. Geological Survey

Viater Resources Division

Vashington, D.C. 20242

State Arencies (28 copies)

Alabama Vater Imorovement Commission State Office Building

Montgomery, Alabama 36104

Arkansas Pollution Control Commission 1100 harrington Avenue

Littie Rock, Arkansas 72202

California Department of Fish and Game

1426 Ninth Street

Sacramento, California 95814

2

Connecticut State Vlater Resources Commission.

Room 22, State Office.Building

650 llain Street

Hartiond, Connecticut 06115 
$\therefore$ Eloricla Department of $\mathrm{Air}$ and Vuter Pollution Control 31.5 South Cadhoun Street

Jaljahassce, Florida 32301

Illinois Environmental Protection Agency State of Illinois

Springfield, Illinois 62706

Illinois Pollution Control Board

283 H. Madison Strect

Chicago, Illinois 60502

Illinois State Water Survey

Champaign, Illinois 61820

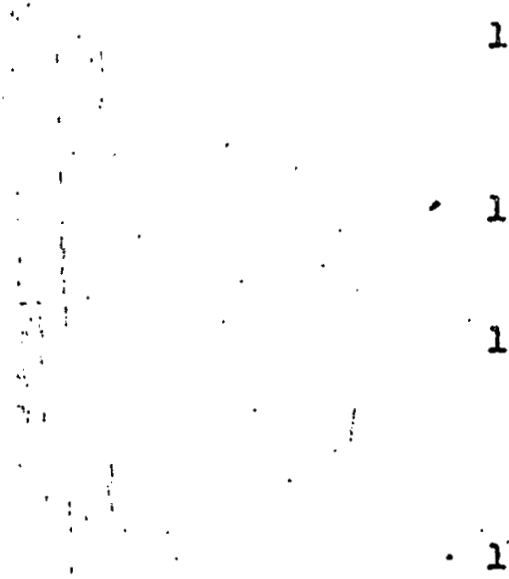

Indiana State Boand of Health

Department of Environmental Health

$1330 \mathrm{~K}$. Nichigan Street

Indianapolis, Indiana 46206

Waine Department of Sea and Shore Fisheries

Director of Research

State of iaine

State House Annex.

Auguista, Maine 04330

Naryland Department of Natural Resources

The State of Haryland

Annapolis, Haryland 21401

1

Massachusetts Department of Natural Resources

Division of Vater Pollution Control

100 Cambridge Street

Boston, Massachusetts 02134

Michigan Department of Naturai Resources Chief, Hater Quality Appraisal Section. Vlater Resources Commission

Stevens T. Mason Building

Lansing, Uichigan 48926

Minnesota Pollution Control Agency

727 Delaware Straet, S.E.

Vinneapolis, Minnesota 55440

Nobraska Hater Pollution Control Commission:

$\therefore=$ State Department of Health

P.O. Box 947.57 , State Kouse Station:

Lincoin, Nebraska" 68509 
Neil limpshire Office of the Governor

Special Assistant for Plaming

Concord, New Hampshire 03301

Nen Hampshire State Technical Services

State of New Hampsire

Concond, Now Hampsinire 03301

New Jerscy Division of Air and Clean. Water

State Department of Health

P.0. Box 2540

Trenton, New Jersey 08625

New York State Atomic and Space

Development Authority

Prograii Nanager

230 Park Avenue

New York, New York 10017

New York State Department of Conservation Assistant Director, Division of Water Resources Albany, New York 12201

New York State Department of Health Division of Pure Vater 84 Holland Avenue Albany, New York 12208

North Carolina Department of Water and Air Resources

P.O. Box 9392

Raleigh, North Carolina 27604

Penrisylvania Department of Public Health Division of Water Quality P.O. Box 90

Harrisburg, Pennsylvania 27108

Tennessee Stream Pollution cóntrol Board Cordell bill Building

Sixth Avenue, North

Nashville, Tennessee 37219

Vermont Department of Water Resources State Orfice Building

Nontpelier, Vermont 05602

Vircinia State Water Control Board Executjue Secretary P.0. Box 11143

Richmond, Virginia 23230 
Washington Stute Depertient of hater Resources

335 Gencral Adminjstration Building

Olympia, hashington 98502

Wisconsin State Department of Natural Resources

Division of Conservation

P.O. Box 4500

Madison, Misconsin 53701

Universities (26 copies)

Indiana University

Department of Microbiology

Bloomington, Indiana $474^{\prime} 01$

1

Johns Hopkins University

Departinent of Geography and Environmental Engineering

Baltimore, Maryland 21218

Johns Hopkins University

Chesapeake Bay Institute

Baltimore, Navyland 21218

Lamont Geological Observatory

Columbia University

Palisades, New York 10964

2

Nessachusetts Institute of Technology

Department of Earth and Planetary Sciences

Cambridge, Massachusetts 02138

2

Yichigan State University

Institute of Water Resources

East Lansing, Nichigan' 48823

$I$

Michigan State University :

Kellogg Biolorical Station

Hickony Conners, Nichigan 49060

Old Dominjon College

Institute of Oceanography

Norfolk, Virginia 23508

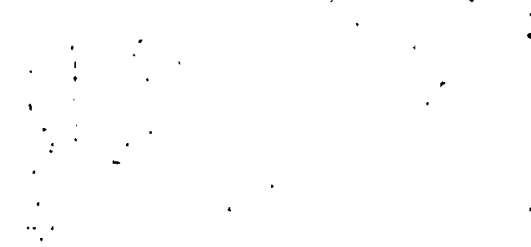

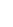

Oregon State University

Water Resources Research Institute

Corvallis, Oregon 97331

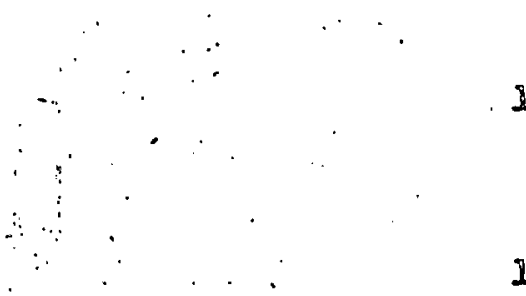

Sar Diego State College

Division of Life Sciences

San Diego State College Foundarion

San Diego, Califomia 92115 ; 
Scripps Insidituion of Oceanography

The University of California

P.0. Box 109

La Jolla, Califormia 92037

Stanford University

Defartment of Civil Engincering

Stanford, California 94305

University of Maryland

Natural Resources Institute

College Park, Maryland 20740

University of Hassachusetts Marine Laboratory Box 128, Lanesville Station

Gloucester, Massachusetts 01930

University of Miami

Institute of Karine Sciences

Niami, Florida 33124

University of Michigan

Great Lakes Research Division

Institute of Scierce and Technology.

Ann Arbor, Michigan 48105

University of Rhode Island

llarragansett Marine Laboratory

Kingston, Rhode Island 02881

University of Vermont

Department of Mechanical Engineering Burlington, Vermont 05401

University of Vashington

College of Fisheries

Fisheries Research Institute

Seattle, Hashington 98105

University of Wisconsin - Milwaukee

Center for Great Lakes Studies

Nilwaukee, Hisconsin 53706

Vanderbilt University

Associate Director

Department of Environmental and Hater Resolirces Engineering

Nashville, Tennessee 37203

Virginia Institute of Marine Science Gloucester Point, Virginia 23062 
Woods Hole Occanographic Institution Senion Scientist

Depantment of Physical Oceanography

Hoods Hole, Hassachusetts 02543

Yale University

Bingharn Oceanographic Laboratory

P.O. Eox 2025, Yale Station

New Haven, Connecticut . 06520

1

Utilitics (48 copies)

Alabama Power Company

600 Nonth I8th Street

Birmingham, Alabama 35202

2

Arkansas Poner and Light

Vice President and Chief Engineer

Sth and Louisiana

Little Rock, Arkansas 72203

1

Baltimore Gas and Flectric Co.

Principal Engineer

531 East Madison Street

Baltimore, Haryland 21203

1.

Boston Edison Co.

Assistant Vice President,

Operations and Engineering

800 Boylston Street

Boston, Massachisetts 02199

1

Carolina Porer and Light Co.

Chief Environmental Engineer

336 Layetteville Strect

Raleigh, North Carolina 27602

1

Cincirnati Gas and Electric Co.

139 East Fourth Street

Cincinnati, Onio 45202

I

Comnonwcalth Edison Co.

Vice President

72 West Adains Street

Chicazo, Illinois 60690

Connecticut Yankee Atomic Power Company

P.0. Box 270

Hantford, Connécticut 06101 
Consoliciated Edison Co. of Nen Yonk, Inc.

Scnio: Vice Pyesident

¿Irving Place

New Yonk, New York 10003

Consumers Poner Co.

Director, Ain and Hater Quality Control

212 liest Kichigan Avenue

Jackson, Michigan 49201

Detroit Edison Company

2000 Second Avenue

Detroit, Michigan 48226

1

Dure Porer Company

Vice President, Enginecring

422 South Church Sireet

Charlotte, North Carolina 28201

Duquesne Light Co.

435 Sixth dvenue

Pittsiurgh, Pa. 15219

Florida Poiler and Light co.

Senior Vice President

4200 Flagler Street

Miani, Florida 33101

Florida Power Corporation

101 Fifth Street S.

St. Petersburg, Florida 33701

Gcongia Power Company

270 Peachtree. Building

Atianta, Georgia 30303

Indiana and Nichigan Electric Co.

2101 Spy Run Avenue

Font liayne, Indiana 46801

Iova Electric Light and Power Company Security Evilding

Cedar Rapids, Iowa 52401

Jenscy Central Power and Light Co. Madison Avenue at Funch Bowl Road

Morristom, New Jersey 07960

Long Is land Lighting Company

250 Old Country Road

Rinsola, New Yonk 11501

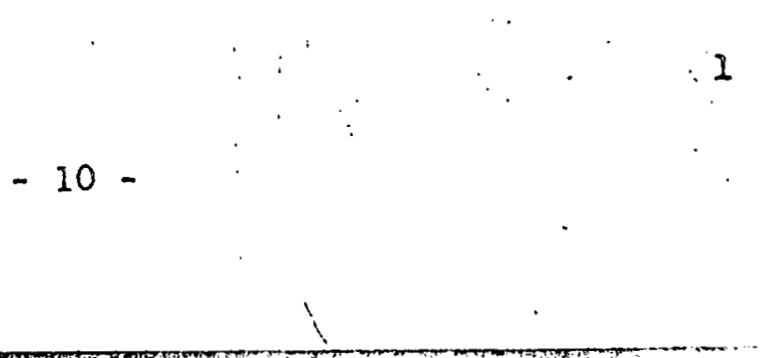


Louisiana Pover and Light Co. 242. Delaironde Strect

Now Orlcans, Louisiana 70114

Mirise Central Porrer Company

Director of Environinental Studies

9 Groen Street

Augusta, laine 014330

Netropolitan Edison Company

P.O. Box 5142

Reading, Pennsylvania 19603

Kiddiescx Essex Power Pool

Public Affairs Oficer

P.O. Box 127

Peabody, Massachusetts 01960

New England Elcctric System

Uanager of Environmental Research 20 Turnpike Road

Hestboro, Massachusetts 01581

Niagara Mohawk Power Corporation

Nine Mile Point Nuclear Station

P. O. Box 32

Lycoming, New York 13093

Attn: Mr. M. A. Silliman

1

2

Northeast Utilities Service Co.

Chief, Environmental Sciences and Services:

P.0. Bo: 270

Hartford, Connecticut 06101

Northern Intiana Public Service Company

5265 Hohman Avenue

Hammond, Indiana 46325

Northern States Power Co.

414 Nicollet Avenue

Minneapolis, Minnesota 55401

Attn: A. V. Dienhandt

Pacific Gas and Elactric

Department of Engineering Research

245 Harket Street

San Francisco, California 94106

1

Pennsylvania Power and Light Co.

901 Hamilton Street

Allentown, Pennsylvania 18101 
Philadelunia Electric Company 2000 Chestnut Strect

Piniladeliphia, Pennsylvania 19105

Potonze Elcctric Poner Company

Assistant to Vice President, Generating:

.\$29 E. Street, WW

Hashington, D.C. 20004

Public Service Co. of Colorado $550 \mathrm{~F}$ ifteenth Street

Denver, Colorado 80202

Public Service Co. of llew Hampshire $1087 \mathrm{ELm}$ Street

Manchester, liew Hampshire 03105

Public Service Electric and Gas 80 Park Place

Newark, New Jersey 07101

Puget Sound Fower and Light Co.

Puget Power Building

Bellevue, Washington 98004

Rochester Gas and Electric Corp.

Chic Environmental Engineer

89 East Avenue

Rochester, Ner York 14604

San Dingo Gas and Electric Company

101 hsh Street

San Diego, California 92101

South Carolina Electric and Gas Co. 323 Naine Street

Columbia, South Carolina 29201

Southern CaIifonia Edison Co.

Associate Chief, Mechanical Engineering

$001 \%$. Fifth Street

Los Angeles, California 90053

Toledo Edison Company

420 Madison Avenue

Toledo, Ohio 43601

Vermont Yankee Nuclear Power Corporation

77 Grove Street

Rutland, Vermont 05701 
Virginia Elcctric Power Co.

Director, Environmental Control

Bo: 1194

Richmond, Virginia 23209

Wisconsin Electric Power Co.

Manager, Cost and Control Div.'

Power Plant Department

231 Vest Vichigan St.

Milwaukee, Wisconsin 53201

1

Wisconsin Michigan Power Company

807 South Oncida Street

Appleton, Wisconsin 54911

1

Visconsin Public Service Corp.

Vice President, Power Generation and Engineering

1029 North Karshall Street

Milwaukee, Hisconsin 53201

1

Yankee Atomic Electric Co.

442 Stuart St.

Boston, Massachusetts 02116

1

other $(64)$

Academy of Naturai Sciences of Philadelphia

Department of Limnology

Nineteenth and Parkway

Philadelolia, Pennsylvania 19405

I

American Public Power Association

2600 Virginia Avenue, N. W.

Washington, D.C. 20037

1

Atomic Inciustrial Forum, Inc.

Legal Projects lianager

850 Thind Avenue

New York, New York 10022

1

Battelle Nemorial Institute

Columbus Laboratories

505 King Avanue

Columbus, Ohio 43201

1

Conneli Aeronautical Laboracory, Inc.

Principal Aeronautical Engineer

- P.O. Box 235

Buffalo, Ne'w York 14221 
Dojamara River Basin Commission

Executive Director

25 Scotcis Road

Trenton, New Jersey 08803

Edison Electric Institute

750 Third Avenue

licis York, llow York 10017

EGSG, Inc.

Starf Oceanographer, Enviromental Equipment Division

10 Matcr straet

Vloods Hole, Massachusetts 02543

E. I. du Pont de lemours $\&$ Co.

Savannah River Laboratory

Aiken, South Carolina 29801

Hanford Engineering Laboratory

Systens Amalysis Department

P.O. Box: 1970

Richland, Washington 99352

National Academy of Science

National Research Council

Division of Earth Sciences

210.2 Constitution Avenue, $\mathrm{NH}$.

Vishington, D.C. 20418

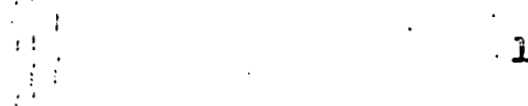

1

1

1

National Rural Electric Cooperative Association

2000 Flonida Avenue, $1 \mathrm{HW}$

Washington, D.C. 20009

New England River Basin Commission, Chaiman

55 Court Street

Boston, Massachusetts 02108

1

Southein Nuclear Engiueering, Inc.

P.O. Box 10

Dunedin, Florida 33528

National Technical Information Service

5285 Port Royal Road

Springfield, Virginia 22151

U.S. Atomic Energy Comission

Division of Technical Information Extension

P.0. Bor 62

Oal: Ridge, Tennessee 37820

Total Distribution - 238 